\title{
The Monk Encounters the Prophet-The Story of the Encounter between Monk Bahīra and Muhammad as It Is Recorded in the Syriac Manuscript of Mardin 259/2
}

\author{
Abjar Bahkou \\ Baylor University, Waco, USA
}

\begin{abstract}
The Syriac communities have been, since the eighth century, orally circulating the story of monk Sargis-Bahīra. Although its oral tradition is widely spread, the written story is not well studied or publicized. ${ }^{1}$ Moreover, the oral story (stories) has been embellished and/or distorted and ends with varying conclusions. At a later period, the Christian version of Bahīra was translated into Armenian and Latin where it gained more popularity, as a means of apology. There are a few versions of the story in different languages such as Arabic, Armenian, Latin, west-Syriac and East-Syriac. It is not the purpose of this study to present a critical edition of the various versions of the story. The purpose is to present an overview that will highlight the important historical events embedded in the story and its religious motifs, with the particular attention to the Syriac manuscript of Mardin 259/2. Throughout the story, the reader will be guided to look at the text within its own historical and apologetic context.
\end{abstract}

Keywords: Christian Arabic Theology, Muslim-Christian dialogue, Church History

\section{The Text of Monk Bahīra}

The text of Monk Bahīra is an evidence of how historical traditions may have been perverted for polemical purposes. The story of the Christian monk Bahīra and his meeting with Muhammad is made the basis for a series of apocalyptic visions and prophecies designed to show that there was nothing at all original in the teachings of the prophet; that he was an arch-fraud, and that he was instigated to practice this fraud by his mentor, who wished to bring the ignorant Arabs to the knowledge of one God. ${ }^{2}$ S. Griffith's comments on the story merit attention:

The best hypothesis seems to be that the Christian story is a clever construct, not lacking in verisimilitude, which builds on well-known Islamic lore, to serve as a literary vehicle for a Christian response to the civil and religious pressure of Islam. It provides the Christian reader not only with a way of religiously accounting for the rise of Islam and the course of history, but also suggests that Islam is actually a misunderstood form of Christianity, and it provides the Christian reader

\footnotetext{
Abjar Bahkou, Ph.D., Senior Lecturer in Arabic Language and Culture, Baylor University.

Correspondence concerning this article should be addressed to 6613 Tejas Dr. Waco TX 76712, USA.

1 Barbara Roggema published a comprehensive study on the legend of Monk Bahira, she mentioned that she consulted this manuscript that is present in the monastery of Saint Gabriel in Turkey. See Barbara Roggema, The Legend of Monk Bahira, L. J. Brill 2009, 240.

2 Ricahard Gotteil, “A Christian Bahīra Legend”, Zeitschriftfür Assyriologie. 13(1898): 189.
} 
with apologetic strategies for rebutting Islamic objections to Christian doctrines. ${ }^{3}$

The essential outline of the story of Bahīra in the Christian sources remains the same in all textual traditions. There are shorter and longer recensions with many variations. The Christian Bahīra was preserved in both the Syriac and the Arabic languages. Much evidence in the text points to the Syriac version as the earliest. ${ }^{4}$ It is evident that throughout the centuries, copyists have changed and interpolated various elements to enhance their apologetic position at the time. While the story of Bahīra in Islamic sources consists of one part, ${ }^{5}$ in the Christian sources, it consists of three parts. The three parts belong to different periods, but are loosely tied together to form a single tradition after the ninth century. According to this written tradition, an itinerant monk, (Išu'yhab, in Syriac, the Arabic version called himMurhib) ${ }^{6}$ whose long journey led him to monk Bahīra, tells the whole story. Išu'yhab encountered Bahīra for eight days, after which Bahīra died.

In the Syriac version, which is the focus of this study, Išu'yhab heard the story, not from the monk himself, but only after his death from a disciple of Sargis-Bahīra named Hakim. Therefore, Hakim is the reporter of the advice which Bahīrais said to have given to Muhammad. Given the tenor of this advice, it may be the case that from the point of view of the narrative, Hakim is introduced precisely to put some distance between the narrator-monk and Sargis-Bahīra in matters of which a well-informed Christian could only disapprove. Although Sargis-Bahīra is an errant, misguided monk, he is also presented as a holy man who works miracles. Even after his death, the text says that his bones miraculously aided in the identification of a murder. Hakim is himself not a monk, but one who as a child had been cured of leprosy at Bahīra's hand when he, at the monk's insistence, came to believe in the "Messiah, the Son of the Living God", the "Messiah God", as he testifies.

In the first part, Bahīra speaks about his journey to Jerusalem and the holy Mount Sinai. On Mount Sinai, he was captured in spirit, not in body, into heaven to watch a vision which related the religious and historical future of the region. In that vision, Bahīra was commanded to warn both the Byzantine and Persian emperors that their kingdoms would be vanquished at the hands of "the son of Ishmael", and "the sons of Ishmael" will dominate and rule up to "twenty four kings" and "within ten weeks". Bahīra obeyed the command of the angel, according to the vision, and informed both emperors, who caused him no harm. The harm, however, came from the hierarchy of the church, accusing him of being a "hatred of the cross". In fact, this happened because he said that only one cross should be placed in the church. Only one cross should be worshipped, since even Christ was crucified on one cross, not on many crosses. Consequently, Bahīra withdrew to the wilderness of Yathrib,

\footnotetext{
${ }^{3}$ Sidney H. Griffith, "Muhammad and the Monk Bahīra: Reflection on a Syriac and Arabic Text from Early Abbasid Times," OriensChristianus. 79(1995): 148.

4 J. Bignami-Odier \& M.G. Levi Della Vida, "Une Version Latine de L'apocalypseSyro-arabe de Serge-Bahira," Mélangesd'Archéologiesd'Histoire 62(1950): 133. Abdul-Massih Saadi, "The story of Monk SargisBahîrâ," Karm. 1(1999): 3 \& 4,225 .

5 Abdul Hameed Siddiqui, The Life of Muhammad, Des Plaines: Library of Islam 1991. A. Guillaume, The Life of Muhammad, A translation of SiratRasul Allah, Oxford University Press, Pakistan Branch, Lahore Karachi 1970.

${ }^{6}$ There are various suggestions about this name. Murhib is Gotteil's choice. Murahab is another possibility, See, R. Gotteil "A Christian Bahîrâ Legend" (2) ZeitschrifefürAssyrilogie 14 (1899): 203-268. Griffith believes that neither of them are known Arabic names. See, Sidney H. Griffith, "Muhammad and the monk Bahira: Reflection on a Syriac and Arabic Text from Early Abbasid Times." OriensChristianus 79 (1995): 148. Another scholar suggested that the text be emended to read "Mawhoob" that is to say "Gift." a reading which would correspond somewhat with the meaning of the Syriac name "Išu'yhab" which means "Jesus has given". The claim is that the letter " $r$ " and " $w$ " can resemble one another in some Arabic hands. See J. Bignami-Odier \& M. G. Levi Della Vida, "Une Version Latine de L'apocalypseSyro-arabe de Serge-Bahira," Mèlangesd'Archèologiesd'Histoire 62(1950): 129. Gero prefers the vocalization "Marhab" and he suggests that it represents elision of the monk's full title and name Mar Išu'yhab, Stephen Gero, "The legend of the Monk Bahīra; the Cult of the Cross and Iconoclasm," in P. Canivet \& J-P. Rey-Coquais (Eds.) La Syrie de Byzance à l'Islam, Institut Francais de Damas Damas 1992, 52.
} 
where he encountered the sons of Ishmael, and he prophesied to them about their future. The sons of Ishmael liked and honored him, and built a cell and dug a well for him, thus among them, he dwelt in peace and tranquility. The sons of Ishmael visited him and were instructed by him. At the end "Bahīra wrote and delivered to them the book, which they called Qur'an." This section ends with two notes. First, it relates that even after the death of Bahīra, the sons of Ishmael were resorting to his grave, over which "a great miracle took place". Second, after Bahīra's death, a Jewish scribe falsified the teaching and the writing of Bahīra, teaching them that "Muhammad is the Paraclete," whom Jesus had promised to send. This apocalyptic vision of the first part owes, according to Griffith, a large debt to the earlier apocalypse of Pseudo-Methodius, itself originally a Syriac composition. In fact in the Arabic version the text refers explicitly to Methodius twice. ${ }^{7}$

The outline of the second part of the story contains how Bahīra first encountered Muhammad, recognizing him among the rest of the nomads, predicting that "he is the one in whom his prophecy will be fulfilled." Afterwards, the story relates many encounters between Muhammad and Bahīra and a string of questions and answers between the two. The catechesis of Muhammad takes place in this juncture. It is in the pretext of a dialogue between Muhammad and Sargis, in a question and answer format. Muhammad poses leading questions, which Bahīra answers in a way which allows the reader to see both a statement of Christian doctrine and, by implication, the normative Islamic position which it is meant to countervail.

In the first place, Sargis explains that he has received his vision about Muhammad and his future from Mt.Sinai, "the place where Moses received his divine visions". And the monk specifies that Muhammad's mission will be "to turn your people away from the worship of image to the worship of the one true God". One recognizes in this purpose what Christian apologists writings in Syriac and Arabic in the early Islamic period were always prepared to acknowledge about Muhammad; he turned the Arabs away from idolatry to the worship of God. As to the identity of the true God, the monk testifies as follows: "I worship the Living God... I profess and believe in His Son, Jesus, the Messiah, and the Holy Spirit." One notices immediately the expression, "His Son Jesus the Messiah" a phrase which in Syriac echoes more the Qur'anic one, "Al-masih

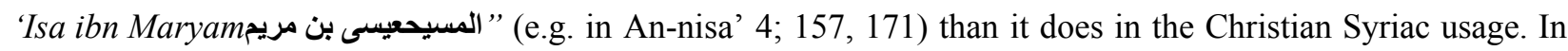
Syriac, Christians customarily spoke simply of "our Lord Jesus, MōranIsh"

In answer to the question about the how one comes to know about such a God, Bahīrareplies, "from the Law and the prophets" this was the answer of all the Christian controversialists in the early Islamic period; many of them developed elaborate apologies for Christianity based on the testimonies drawn from the Law and prophets. This strategy drew its strength from the Qur'an's own prophetology, in which Muhammad's mission is presented as continuing with that of Abraham, Moses and the rest of the prophets. Christians argued that prophecy was truly fulfilled only in the life and ministry of the Lord Jesus. ${ }^{8}$

A major portion of the dialogue is concerned with Christology. The monk confesses, "I am a Christian

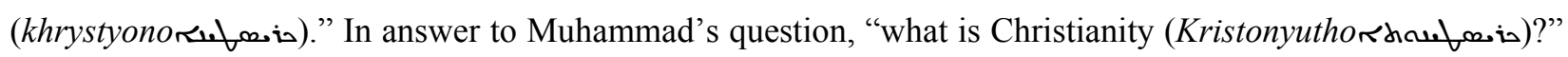
The monk answers that "it is being anointed (Mshihutho)." When Muhammad asked, "What is being anointed?" The monk answers with a quotation from the Qur'an. He says: "The Messiah is the Word of God and His Spirit.

\footnotetext{
7 Sidney H. Griffith, "Muhammad and the monk Bahīra: Reflection on a Syriac and Arabic Text from Early Abbasid Times," Oriens Christianus 79(1995): 150. For the Arabic version, R. Gotteil, “A Christian BahīraLegend" (2) Zeitschrifefür Assyrilogie 14 (1899): 203-268.

8 Sidney H. Griffith, "Muhammad and the monk Bahīra: Reflection on a Syriac and Arabic Text from Early Abbasid Times," Orients Christianus 79(1995): 161.
} 
The Ishmaelites too acknowledge the Messiah, that he is the Word of God and His Spirit." One readily recognizes here the quotation from An-nisa 4: 171, as well as the attempt to elucidate the sense of the term "Messiah" by reference to the root meaning of the verb Meshahwess, "to anoint" then, in answer to Muhammad's question, "Is the Messiah God, prophet, or man?" Bahīra replies that "the Word of God the Father, was sent by God, and came down and dwelt in the womb of the holy Virgin Mary. She became pregnant and gave birth without copulation." When Muhammad wanted to know, "how could a virgin get pregnant without copulation?" the monk gives the answer that "the Word of God came down from heaven and was clothed with a body from the virgin. The Messiah was born from her in a bodily way, although he was God in terms of person and nature." The Christological character of this statement is very clear, insisting as it clearly does, that the Messiah is both "person" and "hypostasis" and "nature", the very terms of the Christological controversy. It is significant that in the form of the story which circulated in the Nestorian traditions, the corresponding passage states only that the virgin "gave birth to a son without copulation, and God became man." The Christological section of the dialogue then concludes with a brief exchange about the crucifixion of Jesus. The monk teaches, in direct contradiction to the Qur'an (see An-nisa' 4: 157), that "the Jews crucified him," and he answered Muhammad's question about why he would worship someone whom the Jews crucified.

In the Syriac version of the Bahirastory, the catechesis of Muhammad is clearly a literary attempt, knowingly to depict Islam as a degraded and simplified form of Christianity, which was further distorted by Jews. It fairly well reflects in its fictional form many of the features of the more formally conceived Christian apologies in the Islamic milieu. And even its fictional motifs are well selected items from the lore of the Muslims, including the Qur'an and the hädith, which the composer of the story has woven into a narrative, which is both apocalyptic and historical in its claims. ${ }^{10}$

The third part departs from the dialectical style of the second part to follow, as in the first part, the apocalyptic genre. Here, the story related several additional apocalyptic visions regarding the reign of the "ten weeks" of the dynasties of "the sons of Ishmael" and their final fall. The emphasis of this part is on the conditions of life under Islam until the projected coming of the Mahdi and the inception of the events of the end-time. There are references, not only to the many disabilities to be suffered by Christians, but pointed references to numerous Christians who will have become Ishmaelites.

These apocalyptic sections are the most important features in the Syriac version, and they occupy by far the most space in the text. This prominence of the apocalyptic genre is not surprising, given the fact that in the Syriac-speaking communities, apocalypses were the most important literary reaction to the challenge of Islam, from the time of the caliph Abd al-Malik (685-705) until the Abbasid revolution.

\section{The Polemical and Religious Context of Bahīra}

Religiously speaking, it is common that the newest religion claims that the older testifies to the truth of the new. Eastern Christians, for instance, developed the episode of "Simon the Elder" mentioned in Luke 2: 25-35, as a way of having a significant figure from the older religion (Judaism) miraculously testify to the new religion. In reaction to this and other Christian interpretations, the Jews composed polemical writings, among them a

\footnotetext{
${ }^{9}$ Gotteil, "A Christian BahīraLegend," Zeitschrifefür Assyrilogie 13(1898), 220 (Syriac version); 14 (1899), 240 (English translation).

${ }^{10}$ Sidney H. Griffith, "Muhammad and the monk Bahira: Reflection on a Syriac and Arabic Text from Early Abbasid Times," Oriens Christianus 79 (1995): 165.
} 
book known as Toledoth Yeshu (the History of Jesus) with the portrayal of a sharply anti-Christian version of the life of Jesus. ${ }^{11}$ Similar stories of testimonies were circulated concerning Buddha and Zoroaster, which lie outside of the scope of this thesis. In a similar way, later Muslim writers articulated many religious types already circulated among other religions and applied them to the early history of Muslims. The story of Bahīrais has no exceptions.

Recent studies have called attention to a number of Syriac compositions of an apocalyptical character, which were produced by Syriac writers in the Syro-Mesopotamian milieu in the Umayyad period, beginning in the reign of the caliph Abd al-Malik (685-705). The Apocalypse of Pseudo-Methodius is the most well-known of these compositions, but in the same breath, one might also mention the Syriac Gospel of the Twelve Apostles, and the so called Edessene Apocalypse. ${ }^{12}$ Reinik and Drijvers have shown that all these texts have their roots deep in the Syriac tradition as far back as Ephraim the Syrian (d. 373), and they rely heavily on motifs found in such earlier works as the Romance of Julian, the Alexander Legend, and the Judas Cyracus Legend. For the most part, these texts seem to have been composed in a Syrian Orthodox milieu, although they became widely popular throughout the Syriac-speaking world. They attempt to make sense of the rise of Islam and the rule of the Muslims in terms of the traditional eastern Christian exegesis of the book of Daniel. In this sense, while the texts are often highly polemical against Islam, they are very much intra-Christian documents. And they would have been readily available to the composer of the Christian Bahīra legend. ${ }^{13}$ Bar Penkaye, for example, a contemporary of the Arab conquests and its repercussion, clearly stated the purpose of his writings as "not to entangle ourselves with complicated narratives, the results of which causes many trouble for ourselves, and make us forget our purpose; that is to demonstrate what God has done for us in His goodness, and what we have dared to do in opposition to him in our wickedness." Thus, Bar Penkaye related the events of the Arab/Muslim conquest as part of a divine plan, prophesied by Daniel. ${ }^{14}$

It is not easy to determine which religious tradition first related the story of Bahīra. The nuclear story of Bahīra, according to the Christian version, was implicitly and/or explicitly referred to by many Christian authors beginning from the early eight century. John of Damascus (d. 749), writing in the early eighth century, pointed out that Muhammad was exposed to the Old and New Testament and was in dialogue with a certain Arian monk. ${ }^{15}$ In the Chronicles of Theophanes (d. 817) and of George Hamartolos (fl. 866), it is reported that Muhammed's wife received reassurances about his experience of revelation from "a monk exiled for false belief" and living among the Arabs. ${ }^{16}$

By the mid-eighth century, it was already clear to writers, such as Anastasius of Sinai, John of Damascus,

11 ToledothYeshu is preserved in several recensions, Aramaic and Hebrew. See E. Bammel, "Christian Origins in Jewish Tradition," New Testament Studies 13(1966-1967) 317-335.

${ }^{12}$ S. H. Griffith, 79(1995): 152.

${ }^{13}$ H. J. W. Drijvers "Christians, Jews and Muslims in Northern Mesopotamia in Early Islamic Times; the Gosple of the Twelve Apostoles and Related Texts," and G. J. Reinink, "The Romance of Julian the Apostate as a source for the Seventh Century Apocalypse," in P. Canivet \& J-P. Rey-Coquias (Eds.) La Syries de Byzanceal'Islam,InstitutFrancais de Damas, Damas 1992, 67-74 \& 75-86. G. J. Reinink, "Pseudo-Methodius: a Concept of History in Response to the Rise of Islam," H. J. W. Drijvers, "The Gospel of the Twelve Apostles: A Syriac Apocalypse from the Early Islamic Period," A. Cameron \& L. I. Conrad (Eds.) The Byzantine and Early Near East (studies in Late Antiquity and Early Islam, I: Problem in the Literary Source Material; Princeton, N.J., 1992) 149-187 \& 189-213.

14 A. Mingana, Sources Syriaques, Mšiha-zkha \& Bar Penkaye, Texteet Traduction (Leipzig, Harrassowits 1908) 176-178.

15 See, Daniel J. Sahas, John of Damascus on Islam; the "heresy of Ishmaelites", Leiden 1972, 132.

${ }^{16}$ Carolus de Boor (Ed.) Theophanis Chronographia (2 vols. Leipzing 1883 \& 1885), Vol. I, 334. Carolus de Boor (Ed.) Georgius Monachus Chronicon (2 vols. Leipzig 1904) Vol. II., 699. 
17 the writer of the Syrian Patriarch John III with the emir 'Umayr Ibn Sa'ad al-Ansari, and the composer of the dialogue between the monk of Bet Hale and an Arab notable, ${ }^{18}$ that Christology was the main issue between Muslim and Christians. In the theological vocabulary of all the contemporary Christian denominations, the label "Arian" fairly well expressed the intra-Christian theological judgment about the Islamic view Isa Ibn Maryam. For "Melkite" and "Jacobite" the further label "Nestorian" served the same purpose. Indeed this Christian characterization of the situation seems even to have found its way back into Islamic apologetical/polemical traditions, for there is yet another episode in the biography of the prophet Muhammad in which he is said to have encountered a monk who recognized his prophetic vocation. According to the tradition, as a young man in the employ of his future wife, Khadijah, Muhammad came once with a merchant caravan to Syria. There a monk whom Islamic tradition calls Nastur (Nestorius) is said to have recognized him as a future prophet. ${ }^{19}$

In the ninth century, the story was even more widely spread and used as a means of apology and polemics by both Christians and Muslims. The polemical letter of Al-KindiRisala al-Kindi in response to an alleged Muslim attacker, al-Hashimi, referred to Bahīraas a heterodox monk, who left from Arabia and won Muhammad away from idolatry, thus making him his disciple. ${ }^{20}$ Corresponding to the version of Ibn Sa'ad, who named the monk Nastur, Al-Kindi incorporated this name, saying the monk's name was Sargis-Bahīra, but he changed his name to Nastur because he followed Nastur's teaching. On the other side, the Mu'tazilite author, al-Jahiz (d. 869), reported to the tenth Abbasid Caliph, al-Muttawakel (d. 861) that "the Christian faith, may God have mercy on you, resembles Manichaeism and, in some of its aspects, is akin to atheism." Al-Jahiz distinguished between his contemporary Christians and those mentioned in the Qur'an. He contended that the Christians concerning whom the Qur'an says "the nearest in loving friendship to those who believe" were not the present Christians, and that "God did not mean these Christians nor their like, i.e., the Melkites and the Jacobites, rather God meant the likes of Bahīra and the monks who were at the service of Salman." 21

By mid-ninth century, the tension between Christian and Muslim power intensified. It was in such an environment that certain Christian polemicists recast the story of Sargis-Bahīra from a conventional hagiographic and apocalyptic story into an apologetic and polemical one.

\section{Date and Authorship of the Text}

To date the Christian Bahīra legend, one must rely on the criteria that suggests a plausible time for its composition. The study of Armand Able, which remains the most plausible one today, suggests that the material in the text reflects the state of affairs in the second half of the first Abbasid century, probably during

\footnotetext{
${ }^{17}$ See, S. H. Griffith, "Anastasios of Sinai, the Hodegos, and the Muslim," Greek Orthodox Theological Review 32(1987): 341-358

${ }^{18}$ See, S. H. Griffith, "Disputes with Muslims in Syriac Christian Text: From Patriarch John (d. 648) to Bar Hebraeus (d. 1286)" in, B. Lewis \& F. Niewöhner (eds.), ReligionsgespracheimMittelalter (Wolfenbütteler Mittelalter-Studien, 4; Wiesbaden, 1992) 257-261.

19 'Abdar-RaūfSa'd, As-Sīrah an-Nabawiyyah, Vol. 1, Beirut 1975, 172.

20 Al-Kindi, Correspondence Between Al-Hashimi and Al-Kindi, Villach, Light of life 1991, 79.

21 J. Finkel (Ed.) Three Essays of Abu 'Othman 'Amr Ibn Bahr al-Jahis (869) (Cairo, al-Salafieh 1963), 14. Salman, like Bahira, being a Christian, recognized Muhammad prophethood through the marks. Salman is referred to Salman al-Farisi, a companion of the Prophet and one of the most popular figure in Muslim legend. According to one tradition, Salman was an enthusiastic Christian, who left his father's house to follow a teacher from whom he learned about the coming prophet. Finally, when he was in Yathrib, he met Muhammad and recognized him from the marks of the prophet which the monk had described to him, Cf. H. Houstsma \& A. Wensick (Eds.), The Encyclopedia of Islam, vol. 4, London, Lazac, 1934, 116-117.
} 
the reign of the al-Ma'mūn (813-833). He bases his conclusion on twofold analysis: the description of, or allusions to, persons and events in Islamic history one finds in the text and the character of the apologetical/polemical arguments the author advances against Islam. ${ }^{22}$

Despite the fact that the written text of the story of Bahīra, in both Christian and Muslim sources, appeared in the ninth century, its oral tradition preceded the text. It is certain that its oral tradition was well distributed among, and well received by, all Christian communities proven by to the fact that it is referenced by various Christian groups and is focused in various editions. As a result, many versions of the story have traces of the peculiarity of each Christian denomination. Additionally, it is evident that the story was developed and augmented to accommodate its apologetic purpose. What applies to the story of Bahira in Christian sources also applies to the same story in Islamic sources.

While the written text is evident in the ninth century for both traditions, the question still arises as to which tradition precedes which, the Christian tradition or the Muslim? Christian sources demonstrate several references of the story which precede any reference in Muslim sources. As a matter of fact, Muslim sources are silent on this story before the ninth century. The silence in the Muslim sources, however, does not eliminate the possibility of its oral circulation among Muslim communities prior to the ninth century. It should be expected, at least, that a certain reaction from the Muslims would arise as they heard the story from their Christian subjects. Whatever the case, there is no reference either in Muslim sources nor in Christian that Muslims relate their own version of story prior to the ninth century. Thus, as far as the documentation is concerned, the oral tradition of Sargis-Bahīra in the Christian tradition precedes the Muslim oral tradition, but only the first part of Bahīra in its earliest form.

Griffith presents a number of items in the Arabic version which suggest its dependence on Syriac source. He affirms that "the Syriac version of the story seems to be the primary one."

Twice the author cites the authority of "Methodius" in reference to the work which scholars now call the Apocalypse of Pseudo-Methodius, an original composition in Syriac of the late seventh century. He cites dates according to the year of Alexander, a convention of the Syriac writers of the Syriac Orthodox Community. Syria (bilād ash-Shàm), the homeland of the Syriac-speaking communities, is the geographical setting of the oppressive treatment of Christians at the hands of Muhammad's Ishmaelite successor, as it is described in the author's second apocalyptic section of the word. These considerations, plus the Arabic version follow the outline established in the Syriac version, argue in behalf of the priority of the Syriac. ${ }^{23}$

Up to the ninth century, the story of Bahīra in the Christian tradition, which comprised only the first part, was totally independent of that in the Islamic tradition. It was only during the ninth century, and in response to the Islamic version of Bahīra, that the story of monk Bahīra (former Sargis) was developed. Thus, the second part of the story of Bahīra in the Christian tradition corresponds, line for line, to Bahīra in the Islamic tradition, but with emphasis on Sargis-Bahīra's role of instruction. To provide the cohesive conclusion, the third part, along with the second one, continued the style of the first part. ${ }^{24}$

\footnotetext{
22 See, A. Abel, "L'Apocalypse de Bahīraet la notion islamique de Mahdi," Annuaire de l'Institut de Philologies et d'HistoireOrientales3(1953) 1- 12. Also, A. Abel "Changementspolitiques et littératureeschatologiquedans le Monde Musulman," Studia Islamica 2(1954): 23-43.

${ }^{23}$ Sidney H. Griffith, "Muhammad and the monk Bahira: Reflection on a Syriac and Arabic Text from Early Abbasid Times." Oriens Christianus 79(1995): 155.

${ }^{24}$ Ibid, 172.
} 


\section{Conclusion}

\section{The Implication of the Text on the Early Christian Muslim Encounter}

In terms of its place in the Christian literature of the Muslim/Christian dialogue in the early Islamic period, the Bahira legend forms a body of imaginative composition which allows their Christian readers not only to fend off the challenge of Islam, but to reinforce in themselves the sense of being in the right. They have defended their faith in the very idiom, and indeed, in the instance of the Bahira legend, in terms of the very tradition which in Islamic lore, to the contrary, suggest the Christian commendation of Islam.

The Bahīra legend had a wide circulation in the Christian communities in the Middle East in both its Syriac and its Arabic versions. As for its value as a historical document, it is of interest chiefly for the light it sheds on the growth and development of Christian controversial literature, beginning in the first Abbasid century. It clearly presumes the prior circulation of the Islamic Bahīra story for its effectiveness. Like the other texts with which we have compared the Bahīra legend, it shows a detailed knowledge of the Qur'an, and of general Islamic religious beliefs and practices. It is likely that it was intended to play a role in discouraging conversion to Islam on the part of socially upwardly mobile Christians. In it one can also see the attempt on the part of Christian to find a theological rational for the appearance and success of Islam in the world. However, the most important thing to notice in this unique document is the fact that in it the author manages to combine in the same work the two literary reactions to Islam that had appeared in the Christian communities, apocalypse and apologetics. Furthermore, in its literary history, the work shows the progression of thought from Syriac to Arabic which parallels the actual growth of the Christian reaction to the religious challenge of Islam, from apocalyptic assessment in traditional theological terms to dialectical engagement in inter-religious controversy.

Other texts have been published since the years 1889-1903, not including the manuscript that is being edited in this study. ${ }^{25}$ But few scholars have paid attention to them as exercises in Christian literary apologetics. Rather, the works have mostly attracted the attention of scholars turned either on tracing the history of Christian apocalyptic text, or on investigating the many reports, Muslim as well as Christian, of Muhammad's encounter with monk Sargis-Bahira, whose principal claim to fame in Islamic lore is to have recognized the signs of prophethood in connection with the person of the youthful Muhammad. ${ }^{26}$ This state of affairs allows us to conclude that the work was popular among Arab Christian readers, without providing enough evidence to chart its history in any more concrete way. ${ }^{27}$

\section{References}

Abdar-RaūfSa'd. (1975). As-Sìrah an-Nabawiyyah (Vol. 1). Beirut: Library of Lebanon.

Abel, A. (1953). L'ApocalypsedeBahīraet la notion Islamique de Mahdi. Annuaire de l'Institut de Philologiesetd'Histoire Orientales, 3, 1-12.

Abel, A. (1954). Changementspolitiques et littératureeschatologiquedans le Monde Musulman. Studia Islamica, 2, 23-43.

Al-Kindi. (1991). Correspondence between Al-Hashimi and Al-Kindi. Villach: Light of Life.

Bammel, E. (1966). Christian origins in Jewish tradition. New Testament Studies, 13, 317-335.

\footnotetext{
${ }^{25}$ Richared Gotteil, based his edition on three manuscripts from the fifteenth, the sixteenth and seventeenth centuries. Cfr. Richard Gotteil, “A Christian Bahîrâ Legend” Zeitschriftfür Assyriologie 13 (1898): 189-201.

${ }^{26}$ Stephen Gero, "The legend of the Monk Bahira; the Cult of the Cross and Iconoclasm," in P. Canivet \& J-P. Rey-Coquais (Eds.) La Syrie de Byzanceà l'Islam, Institut Francais de Damas Damas1992, 47-57.

27 Sidney H. Griffith, "Muhammad and the monk Bahira: Reflection on a Syriac and Arabic Text from Early Abbasid Times." Oriens Christianus 79(1995): 147.
} 
Bignami-Odier, J., \& Levi Della Vida, M. G. (1950). Une Version Latine de L'apocalypseSyro-arabe de Serge-Bahira. Mèlangesd' Archéologiesd' Histoire, 62, 133-153.

Cotteil, R. (1898). A Christian Bahīra legend. Zeitschrifefür Assyrilogie, 13, 189-242.

Cotteil, R. (1899). A Christian Bahīra legend. ZeitschrifefürAssyrilogie, 14, 203-268.

Cotteil, R. (1900). A Christian Bahīra legend. Zeitschrifefür Assyrilogie, 15, 56-102.

Cotteil, R. (1903). A Christian Bahīra legend. ZeitschrifefürAssyrilogie, 17, 125-166.

De Boor, C. (Ed.). (1883). Theophanis Chronographia (2 vols, Vol. I). Leipzing: Leipzig University Press.

De Boor, C. (Ed.). (1904). Georgius Monachus Chronicon (2 vols, Vol. II). Leipzig: Leipzig University Press.

Drijvers, H. J. W. (1992). Christians, Jews and Muslims in Northern Mesopotamia in early Islamic times; the gosple of the twelve Apostoles and related texts. In P. Canivet \& J-P. Rey-Coquias (Eds.), La Syries de Byzance a l'Islam (pp. 67-74). Damas: Institut Francais de Damas.

Drijvers, H. J. W. (1992). The gospel of the twelve Apostles: A Syriac Apocalypse from the early Islamic period. In A. Cameron \& L. I. Conrad (Eds.), The Byzantine and early near East (pp. 189-213). (studies in Late Antiquity and Early Islam, I: Problem in the Literary Source Material; Princeton, N. J.)

Finkel, J. (Ed.). (1963). Three essays of Abu 'Othman 'Amr Ibn Bahr al-Jahis (869). Cairo: al-Salafieh.

Gero, S. (1992). The legend of the Monk Bahira; the Cult of the cross and Iconoclasm. In P. Canivet \& J-P. Rey-Coquais (Eds.), La Syrie de Byzance à l'Islam (pp. 47-57). Damas: Institut Francais de Damas.

Griffith, S. H. (1987). Anastasios of Sinai, the Hodegos, and the Muslim. Greek Orthodox Theological Review, 32, $341-358$.

Griffith, S. H. (1992). Disputes with Muslims in Syriac Christian text: From Patriarch John (d. 648) to Bar Hebraeus (d. 1286). In B. Lewis \& F. Niewöhner (Eds.), Religionsgesprache im Mittelalter (pp. 257-261). Wiesbaden: Wolfenbütteler Mittelalter-Studien.

Griffith, S. H. (1995). Muhammad and the monk Bahira: Reflection on a Syriac and Arabic text from early Abbasid times. Oriens Christianus, 79, 147.

Guillaume, A. (1970). The life of Muhammad, a translation of Sirat Rasul Allah. Lahore, Karachi: Oxford University Press, Pakistan Branch.

Hebraeus, B. (1872). Chronicon Ecclessiasticum (Vol. II, Ed. J. Abbeloos and T. Lamy). Lovanii: Excudebat car, Lovanii.

Houstsma, H., \& Wensick, A. (Eds.). (1934). The encyclopedia of Islam (Vol. 4). London: Lazac.

Mingana. (1908). Sources Syriaques, Mšiha-zkha \& Bar Penkaye, Texte et Traduction. Leipzig: Harrassowits.

Perlmann, M. (1954). A legendary story of Ka'bal al-Ahbar's Conversion of Islam. Joshua star Memorial Volume. New York: Jewish Social Studies.

Reinink, G. J. (1992). Pseudo-Methodius: A concept of history in response to the rise of Islam. In A. Cameron \& L. I. Conrad (Eds.), The Byzantine and early near East (pp. 149-187). (studies in Late Antiquity and Early Islam, I: Problem in the Literary Source Material; Princeton, N. J.).

Reinink, G. J. (1992). The Romance of Julian the Apostate as a source for the seventh century Apocalypse. In P. Canivet \& J-P. Rey-Coquias (Eds.), La Syries de Byzance a l'Islam (pp. 75-86). Damas: Institut Francais de Damas.

Saadi, A. M. (1999). The story of Monk Sargis Bahira. Karmo, 1, $3 \& 4$, 22-50.

Sahas, D. J. (1972). John of Damascus on Islam; the "heresy of Ishmaelites". Leiden: Brill.

Siddiqui, A. H. (1991). The life of Muhammad. Des Plaines: Library of Islam. 